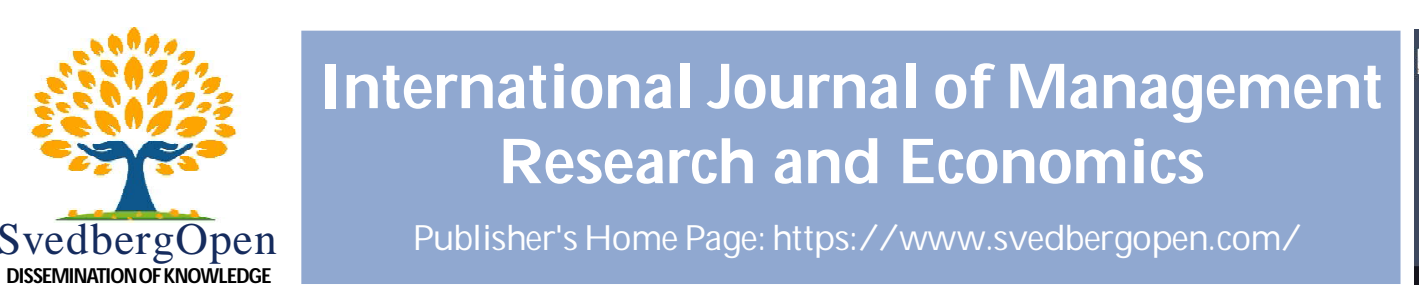

DISSEMINATONOFKNOWLEDGE

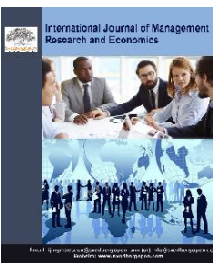

\title{
Capital Investment Appraisal Report for AYR Co.: Comparative Analysis of Project Aspire vs Wolf
}

\author{
Sixbert Sangwa ${ }^{1 *}$ \\ ${ }^{1}$ University of South Wales, Pontypridd, UK.. E-mail: sangwamukiza@gmail.com
}

\section{Article Info}

Volume 1, Issue 4, October 2021

Received : 17 April 2021

Accepted : 12 September 2021

Published : 05 October 2021

doi: 10.51483/IJMRE.1.4.2021.15-23

\begin{abstract}
This report analyses AYR Co.'s two project investment proposals, namely Aspire and Wolf, to determine each project's future success. Based on provided projects information, the report advises Directors of AYR Co. on their planned capital expenditures. Based on some assumptions, the Net Present Value (NPV), Internal Rate of Return (IRR) and projects' payback periods were calculated. Despite the fact that both projects have equal IRR, the project aspire has been recommended for AYR Co.'s management, due to its great cash flows compared to the project Wolf's. However, a number of other factors to be considered has been highlighted and financial sources criticized.

Keywords: Strategic Financial Management, Capital Budgeting, Debt, Cost of Capital, Internal Rate of Return, Stock

(C) 2021 Sixbert Sangwa. This is an open access article under the CC BY license (https://creativecommons.org/licenses/by/4.0/), which permits unrestricted use, distribution, and reproduction in any medium, provided you give appropriate credit to the original author(s) and the source, provide a link to the Creative Commons license, and indicate if changes were made.
\end{abstract}

\section{Introduction}

The capital investment appraisal is part of the planning process that helps to examine the firm's short-term and long-term investments. There are a number of methods used in this process such as Net Present Value (NPV), Internal Rate of Return (IRR), Payback period, Profitability index, etc. the current report will only be limited to the first three methods. Since the report analyses AYR Co's two projects that have the purpose of increasing the company's market share, our analysis will focus more on projects ability to generate cash flows. Unfortunately, this analysis doesn't cover the company's business strategy, which is more recommended. However, some of other factors that need to be analyzed before deciding on a potential project to undertake are surfaced in this report.

\subsection{Methodology}

As mentioned above this report uses three main methods of appraising capital investments which are: the NPV, IRR and payback period. The two first methods are based on the discounted method or time value of money (Scicluna, 2018).

a) Net Present Value (NPV): This technique measures the cash in-flows of an initial investment at a particular time and at a given discount rate as per the below formula:

\footnotetext{
* Corresponding author: Sixbert Sangwa, University of South Wales, Pontypridd, UK.. E-mail: sangwamukiza@gmail.com
} 
$N P V=-C_{o}+\frac{C_{1}}{1+r}+\frac{C_{1}}{(1+r)^{2}}+\ldots+$

$-C_{0}=$ Initial Investment

$C=$ Cash Flow

$r=$ Discount Rate

$T=$ Time

\section{Abbreviated}

$$
N P V=-C_{o}+\sum_{i=1}^{T} \frac{C_{i}}{(1+r)^{i}}
$$

Source: PreMBA (2018)

The higher the NPV, the more desirable is the project, hence all firms' objective is to drive to a positive NPV. However, working under higher interest rate increases the discount rate which, in retour reduces the value of the NPV of a capital investment.

Internal Rate of Return (IRR): This is the discount rate which brings the value of NPV to zero. IRR measures the efficiency of a capital such that if the cost of capital investment is higher than the IRR, the project is likely to be rejected (Capital Investment, 2018). Calculating the IRR is simply equating the NPV to zero as follow:

$$
0=C F_{0}+\frac{C F_{1}}{(1+I R R)}+\frac{C F_{2}}{(1+I R R)^{2}}+\frac{C F_{3}}{(1+I R R)^{3}}+\ldots+\frac{C F_{n}}{(1+I R R)^{n}}
$$

Or

$$
0=N P V=\sum_{n=0}^{n} \frac{C F_{n}}{(1+I R R)^{n}}
$$

where

$C F_{0}=$ Initial Investment/Outlay

$C F_{1}, C F_{2}, C F_{3} \ldots C F_{n}=$ Cash flows

$n=$ Each Period

$N=$ Holding Period

$N P V=$ Net Present Value

$I R R=$ Internal Rate of Returns

Source: Finance Formula (2018)

c) Payback Period: This refers to the time required to get back the initial investment. Always projects that have shorter payback periods are more preferred.

In order to calculate the payback period, we have used the formula given by Irfanullah (2013) for projects with uneven cash flows:

$$
\text { Payback Period }=\stackrel{A+}{C}
$$

where:

$\boldsymbol{A}:$ is the last period with a negative cumulative cash flow;

$\boldsymbol{B}$ : is the absolute value of cumulative cash flow at the end of the period A; 
$C$ : is the total cash flow during the period after A.

However, due to some information that could be interpreted differently or was not clear in our analysis, we made use of assumptions.

\subsection{Assumptions}

\subsubsection{Project Aspire}

- We have taken the market research expenditures as a sunk cost because it is already equally spent and can't be recovered for both projects, hence the $\$ 120,000$ was not included in our calculations for both projects (Scicluna, 2018).

- The project period and initial investment are equal for both projects and are respectively five years and \$2,250,000.

- We have considered a scrap (Salvage) value of \$375,000 as a taxable cash inflow at the end of investment period (i.e., year 5).

- We have ignored a change in working capital equivalent to $\$ 140,000$ due to the fact that:

- There is no clear information on whether this money will make change on cash flows

- It's not also clear whether this capital will be equally distributed throughout the investment period (each year) or whether it tracks the growth of spending rates.

Therefore, we decided to not take into account this working capital because as Leonidas (2018) suggests: "these details are critical for us to decide if the working capital increases or decreases the cash flows during the investment period of the project".

- Since project aspire has capital allowances, we have considered relevant tax benefits as cash inflows. This is because capital allowance themselves are not cash flows but allowable tax depreciations that reduce tax obligations (Scicluna, 2018).

- We have considered the Corporation tax of $20 \%$ which is paid one year in arrears and we used this rate to calculate the tax benefits relevant to capital allowances.

- While we assumed that the discount rate equals the cost of capital (10\%), we have also not taken into account the depreciation of non-current assets since these last are not part of our calculations (Scicluna, 2018).

Project Wolf: The above assumptions also apply to project Wolf, except the fact that this project doesn't have both the scrap value and the capital allowances.

\section{Project Investment Analysis}

AYR Co. is indifferent between two potential projects that aim to increase its market share. In order to recommend either project Aspire or project Wolf, we have analyzed these project below.

\subsection{Calculations and Findings}

In all of our calculations, we have kept in mind the assumptions made in the previous chapter. Detailed calculations are available on the appendices.

\subsubsection{Net Present Value}

This is a very effective and common technique in evaluating projects which analyses the discounted cash flows, hence the future uncertainty of cash flows is compensated. Since the cash earned in future are discounted to present time, it allows good comparison between the cash flows. When this difference (revenues minus costs) is positive, the project is accepted. For two independent projects, the one with greater NPV should be selected.

In order to calculate the NPV for both projects, we used a discount rate of $10 \%$ to discount all cash flows to their present values and made a difference (cash inflows minus cash outflows). The findings are shown in Table 1.

Table 1: Net Present Value

\begin{tabular}{|l|c|c|}
\hline Project & Project Aspire & Project Wolf \\
\hline Net Present Value & 424,845 & $\$ 379,801$ \\
\hline
\end{tabular}

Positive net profit value means profit, hence projects have to be accepted and compared between them and against other metrics as we will see in the IRR below: 


\subsubsection{Internal Rate of Return (IRR)}

The IRR is that discount rate that occurs when a project is break even (Sham, 2018). It is used to determine the amount of return on investment that an investor can expect from a project. The decision to accept a project is based on whether its IRR is higher than the cost of financing; the bigger IRR, the more attractive is the project. In our case, the cost of capital is $10 \%$ and we are expecting greater project to exceed this financing cost.

In order to calculate the IRR for each project, an excel sheet with IRR formula was used for automatic calculation once the net cash flows are entered as parameters.

\begin{tabular}{|l|c|c|}
\hline \multicolumn{2}{|l|}{ Table 2: Internal Rate of Return } \\
\hline Project & Project Aspire & Project Wolf \\
\hline IRR & $17 \%$ & $17 \%$ \\
\hline
\end{tabular}

\subsubsection{Payback Period}

Contrary to the previous method, Payback period is the simplest decision tool, which doesn't normally take into account the time value of money. However, it commonly used "to determine the attractiveness of a project, especially if the company is looking for investments that have fast turnaround times" (Bierman and Smidt, 2007). By using the Irfanullah's formula (2013) we have obtained the following results:

\begin{tabular}{|l|c|c|}
\hline Table 3: Payback Period \\
\hline Project & Project Aspire & Project Wolf \\
\hline Payback Period & 3.42 & 3.07 \\
\hline
\end{tabular}

\subsection{Interpretations and Recommendations}

In this section, we will interpret the above findings to draw a recommendation for AYR Co. over the most desirable project to be undertaken.

\begin{tabular}{|l|c|c|c|}
\hline \multicolumn{2}{|l|}{ Table 4: Summary of Findings } \\
\hline Project & NPV & IRR & Payback Period \\
\hline Project Aspire & $\$ 424,845$ & $17 \%$ & 3.42 Years \\
\hline Project Wolf & $\$ 379,801$ & $17 \%$ & 3.07 Years \\
\hline
\end{tabular}

Based on the findings with these three techniques, we recommend AYR Co. to undertake the project Aspire instead Wolf of because of the following reasons:

Net Present Value: The project Aspire has the highest NPV compared to the project Aspire, which means a big difference between cash inflows and cash outflows during the examined period of time. Obviously, project Aspire will utilize fewer costs to generate more income than project Wolf. Bierman and Smidt (2007) suggest that for any two independent project, we should select the one with a positive NPV or with the highest NPV of the investment budget. In our case choosing the project Aspire will add more value to the company than choosing to undertake project Wolf. However, looking at the IRR alone, we are indifferent between two projects.

Internal Rate of Return (IRR): With this technique we have arrived at the same IRR of $17 \%$ for each project, which can make us indifferent between the two projects. However, the project of our choice is Aspire because of its greater NPV, meaning ability to generate more cash inflows than the project Wolf.

On the other hand, the project Wolf is also not worth to be rejected because its IRR is greater than the cost of Capital investment ( $10 \%$ in our case) which means that this project can also add value to the AYR Co.

Briefly, although both projects have equal IRRs which is above the minimum rate of $10 \%$, project Aspire must be selected first because it has the highest NPV, hence can generate more cash flows than project Wolf. 
Payback Period: While it will take only 3.07 years for the project Wolf to get back its initial investment, the project Aspire will need 3.42 years to pay back its investment. Although project Aspire has a bit longer payback period than Wolf, we still advise to choose project Aspire because it will generate more cash inflows within the investment period and almost in the same year than Wolf. Therefore project Aspire is still more desirable for AYR Co. than project Wolf.

\subsection{Other Factors to Consider}

In capital investment decisions, there is a number of other more factors that should be considered.

Company Culture: If undertaking a new project like Aspire can interfere with the company culture and values, for example by changing the communication style, it is advisable that the company makes careful analysis and decide accordingly. David (2018) gives an example where an automation system can change the team dynamism on a factory floor, hence managers should study the effect that a project can have on the company culture before taking any capital investment decision. In our case, AYR Co should also analyze the effects of the project Aspire on the corporate operations and culture, to see if it can fit in.

Strategy and Cannibalization Effect: This happens when a new product breaks the sales of another one. If this may be the case for project Aspire over the existing products/services, AYR Co should consider the alternative. On the other hand, the project Aspire may appeal to existing customers while project Wolf may appeals to different type of customers, which is absolutely good on the company's strategic view point (Leonidas, 2018). If these are the cases, Wolf would be more desirable.

Economy and Politics: In our case specifically, economic and political factors are also important to our analysis because they can affect the rates of interest and tax paid or cause inflation.

Environmental and Ethical Concerns: While ethical concerns are to be considered in capital investment, it has been argued that the most financially attractive options often have more impact, on environment, than the more expensive options (David, 2018). This calls for managers to become environmentally conscious when choosing affordable project.

Personnel: If AYR Co. has skilled personnel on board or can recruit one, then it still has wider choose. Otherwise, this non-financial factor should also be assessed.

Industry and Competition: Beyond other things we also have to analyze the industry and market competition, company hierarchy as well as economic and financial trends.

\subsection{Sources of Financing}

In this section we discuss the two sources of finance that are being considered by the board of AYR Co. These sources are Equity and Debt, which respectively consist of issuing new shares and borrowing money from lenders. We will also try to analyze their costs and their effects on Weighted Average Cost of Capital (WACC) and on potential stakeholders.

Table 5: Intended Financing Sources for AYR Co.

\begin{tabular}{|l|c|c|}
\hline Capital Employed & $\mathbf{\$ m n}$ & \% per source \\
\hline Equity Holder Funds & 20 & 52.63 \\
\hline Long Term Debt & 18 & 47.37 \\
\hline Total & $\mathbf{3 8}$ & $\mathbf{1 0 0}$ \\
\hline Source: AF4S31 Assessment 2 & \\
\hline
\end{tabular}

\subsubsection{Description of Equity and Debt}

Equity Financing is that process of raising the firm's capital by selling shares. This is now an option for AYR Co., if the company still has shares that are not yet issued to stockholders, so it can issue them in order to raise funds for their new project. The process involves both the common shares and preferred shares as well as the share warrants. However, raising capital from investors refers to selling part of ownership, where investors are expecting return from their investments, in belief that the company has potential to make more money (Rosemary, 2018). In this regard, if AYR Co. has existing 
stockholders, it may be required to declare their dividends. Otherwise the company needs to think twice before engaging in shared ownership because, although this option has advantages of capital investment, investors not only share profits with the company, they also have a say on how the business is run (State of Queensland, 2017); therefore more analysis is needed on how much control the company would surrender.

On the other hand, Debt Financing occurs when a company raises its capital through borrowing from banks or other lenders. In this process, the company may also use debt instruments like bonds, notes, bonds or other agreements with the lender. Once credit received or debt instruments are sold, the company should pay the creditors' or debt instrument holders of the principal amount plus periodic interests (Helbæk et al., 2010). In our case, we would recommend AYR Co. to consider this option first.

Therefore, the decision on a source of financing involves both the cost-benefit and the financial and business risks analysis.

\subsubsection{Cost of Each Type of Financing}

While the cost of debt is equivalent to the interest that the company pays on its borrowings, the cost of equity is now the return that a company pays to its investors. However, as discussed above equity financing is more expensive and complex than debt financing. This is because in debt financing, interest payments are tax deductible. To better understand this let's consider taking a loan from a bank with interest rate of $6 \%$, while our corporate tax rate remains $20 \%$. The cost of financing will now be: $(0.06) *(1-0.2)=4.8 \%$

In equity financing, investors take on risks expecting to be compensated by higher returns. With belief that the company has potential to make money, they expect its performance to be better, which increase their stock prices and gives them high dividends. Apart from the fact that stockholders participate in the potential rise in earnings, they finally lose everything if the company goes bankrupt. All of these risks should be compensated by more returns, which indicate how expensive this financing is (Equity Master, 2010). Additionally, no tax can be deducted from them as this is the case for debt lenders.

On the other hand, while debt financing increases risks for the borrower because in case of bankrupt the lender has first claim on company assets (Equity Master, 2010), it's the cheapest. If AYR Co. decides to go for debt financing, it will be paying the lender on regular basis and the cost of debt will only be determined by interest rate. AYR Co. would also benefit from interest tax.

\subsubsection{Effect on the WACC}

Although it's not always the case, debt is likely to be a cheaper source of finance than equity, as discussed above. It's now up to AYR Co. to decide over a preferred source of financing based on an in-depth analysis of crosscutting factors. However, whichever option the company takes will have an effect on the WACC.

If the company chooses to go for equity financing, the cost of capital may increase due to increase in share. Contrary, debt financing may reduce the cost of capital due to this increase the portion of the cheaper source of funding (Scicluna, 2018). However, AYR Co. should first analyze the interest rate which can affect annual cash flows (Madura, 2017).

\subsubsection{Impact on Potential Stakeholders}

The two source of financing have effects on either the company ownership or profitability, which in return affect Stockholders and Lenders. For example, debt financing affects the company's net income due to regular payments of interests to lenders. Although the process doesn't affect existing stockholders' ownership, it increases the company's risks by increasing liabilities that include the payable borrowed capital, interests and/or penalties depending on the agreement. For the case of equity financing, the process dilutes existing stockholders ownership and their interest in the company, if they are not the ones who buy new shares.

\section{Conclusion}

The results of the three investment appraisal methods have allowed us to choose project Aspire over project Wolf because of project Aspire's ability to pay back its investment within the investment period, its IRR which is bigger than the cost of capital investment and foremostly because of its ability to generate more cash flows than project Wolf. However, our choice for project Aspire is also sensitive to another number of factors such as the company culture, availability of skilled personnel, environmental and ethical concerns as well as the type of financing. We recommend AYR Co to undertake the project Aspire assuming that other considerations are given account. In terms of choosing a 
source of financing, we have analyzed a number of factors that affect cash flows such as inflation, expected return on investment, management and shared ownership, financial risks, etc. Although we believe that further analysis is needed, we have recommended the company to consider debt financing over equity financing source due to the latter being more expensive than debt financing.

\section{Acknowledgment}

This work was carried out as part of the author's learning path at the University of South Wales in the United Kingdom, which is why the author would like to thank the entire academic team for this opportunity and more particularly Dr. Chris Benjamin for his consistent supervision and advice on the project and Leonidas Stergiou, my fellow student who remained closer to inspire and added his incredible contributions.

\section{References}

Bierman, H. and Smidt, S. (2007). The Capital Budgeting Decision. New York and London: Routledge.

Capital Investment. (2018). Capital Investment Appraisal/Appraisal Techniques. available at http://www.capitalinvestment.co.uk/capital-investment-appraisal.php. Accessed on March 25, 2018.

David, I. (2018). Qualitative Factors in Capital Investment Decisions. available at http://smallbusiness.chron.com/ qualitative-factors-capital-investment-decisions-73769.html. Accessed on March 19, 2018.

Equity Master. (2010). Equity or Debt: Which is Cheaper?. available at https://www.equitymaster.com/detail.asp?date=10/ 13/2010\&story=2\&title=Equity-or-Debt-Which-is-cheaper. Accessed on March 20, 2018.

Finance Formulas. (2018). Net Present Value. available at http://financeformulas.net/Net_Present_Value.html. Accessed on March 25, 2018.

Helbæk, M., Lindset, S. and McLellan, B. (2010). Corporate Finance. Maidenhead, Berkshire: Open University Press/ McGraw-Hill Education.

Irfanullah, J. (2013). Payback Period. available at https://accountingexplained.com/managerial/capital-budgeting/paybackperiod. Accessed on March 25, 2018.

Madura, J. (2017). International Financial Management. US: Cengage Learning Custom Publication.

PreMBA. (2018). Evaluating Cash Flows: NPV \& IRR. available at http://ci.columbia.edu/ci/premba_test/c0332/s5/ s5_5.html. Accessed on March 25, 2018.

Rosemary, P. (2018). 6 Types of Equity Financing for Small Business. Avoid Loans and Credit Debt By Financing with Equity. available at https://www.thebalance.com/types-of-equity-financing-for-small-business-393181. Accessed on March 19, 2018.

Scicluna, C. (2018). Investment Appraisal II. In: Strategic Financial Management. University of South Wales, pp. 2-19. available at https://vle-usw.unicaf.org/mod/resource/view.php?id=3642 1. Accessed on March 12, 2018.

Scicluna, C. (2018). Investment Appraisal I. In: Strategic Financial Management. University of South Wales, pp. 2-25. available at https://vle-usw.unicaf.org/mod/resource/view.php?id=36417. Accessed on March 25, 2018.

Scicluna, C. (2018). WACC. In: Strategic Financial Management. pp. 2-11. available at https://vle-usw.unicaf.org/mod/ resource/view.php?id=36401. Accessed on March 25, 2018.

Scicluna, C. (2018). Capital Structure and Gearing. In: AF4S31 Strategic Financial Management. University of South Wales, pp. 1-12. available at https://vle-usw.unicaf.org/mod/resource/view.php?id=36404. Accessed on March 25,2018 .

Scicluna, C. (2018). Cost of Capital - Introduction to Cost of Debt. In: Strategic Financial Management. University of South Wales, pp. 6-7, 15. available at https://vle-usw.unicaf.org/mod/resource/view.php?id=36399. Accessed on March 25, 2018.

Sham, G. (2018). Capital Budgeting: Capital Budgeting Decision Tools. available at https://www.investopedia.com/ university/capital-budgeting/decision-tools.asp. Accessed on March 26, 2018. 


\section{Appendices}

\section{A. Calculation for Project Aspire}

\section{PROJECTASPIRE}

\begin{tabular}{lrrrrrrr}
\hline & Year 0 & Year 1 & Year 2 & Year 3 & Year 4 & Year 5 & Year 6 \\
\hline Capital spending & $(\$ 2,250,000)$ & & & & & & \\
\hline Salvage value & & & & & & $\$ 375,000$ & \\
\hline Cash Inflows & & $\$ 650,000$ & $\$ 698,750$ & $\$ 751,156$ & $\$ 807,493$ & $\$ 868,055$ & \\
\hline Variable Costs & $(\$ 27,000)$ & $(\$ 28,823)$ & $(\$ 30,768)$ & $(\$ 32,845)$ & $(\$ 35,062)$ & \\
\hline EBIT & $\$ 623,000$ & $\$ 669,927$ & $\$ 720,388$ & $\$ 774,648$ & $\$ 1,207,993$ & \\
\hline Taxes (20\%) & $\$ 0$ & $(\$ 124,600)$ & $(\$ 133,985)$ & $(\$ 144,078)$ & $(\$ 154,930)$ & $\$ 241,599$ \\
\hline Capital Allowance & & $\$ 600,000$ & $\$ 390,000$ & $\$ 345,000$ & $\$ 300,000$ & $\$ 240,000$ & \\
\hline Tax benefits & $\$ 0$ & $\$ 120,000$ & $\$ 78,000$ & $\$ 69,000$ & $\$ 60,000$ & $\$ 48,000$ \\
\hline Net Cash Flows & $(\$ 2,250,000)$ & $\$ 623,000$ & $\$ 665,327$ & $\$ 664,403$ & $\$ 699,570$ & $\$ 1,113,063$ & $(\$ 193,599)$ \\
\hline Cumulative Cash Flows & $(\$ 2,250,000)$ & $(\$ 1,627,000)$ & $(\$ 961,673)$ & $(\$ 297,270)$ & $\$ 402,300$ & $\$ 1,515,363$ & $\$ 1,321,764$ \\
\hline & & & & & & & \\
\hline Discount Factor & 1 & 0.91 & 0.83 & 0.75 & 0.68 & 0.62 & 0.56 \\
\hline Present Value & $(\$ 2,250,000)$ & $\$ 566,930$ & $\$ 552,221$ & $\$ 498,302$ & $\$ 475,708$ & $\$ 690,099$ & $(\$ 108,415)$ \\
\hline Net Present Value (NPV) & & & & & & & $\$ 424,845$ \\
\hline $\begin{array}{l}\text { Internal Rate of Return } \\
\text { (IRR) }\end{array}$ & & & & & & $17 \%$ \\
\hline
\end{tabular}

YEAR

$\begin{array}{cc}\text { Net CASH } & \text { ACCUMULATED CASH } \\ \text { FLOW } & \text { FLOW }\end{array}$

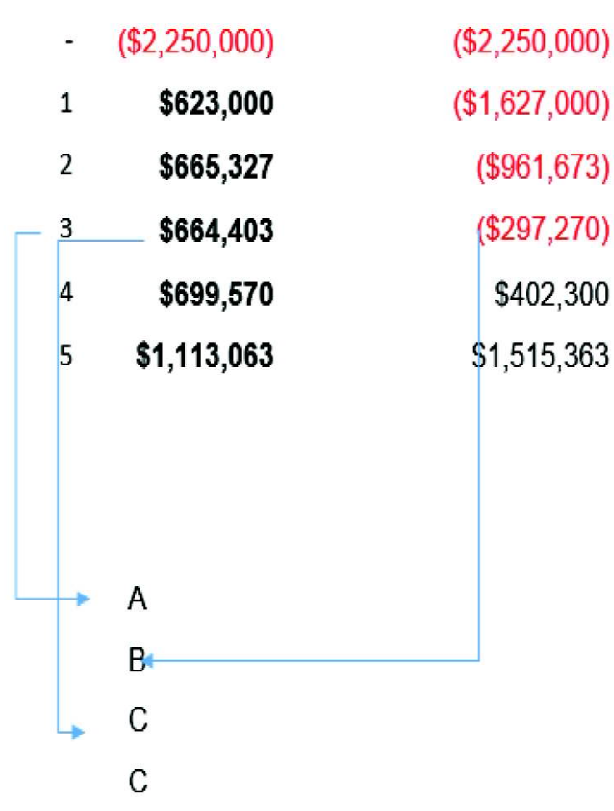

To calculate the payback period, we have used the formula given by Iffanullah (2018) which is used for uneven cash flows:

$$
\text { Payback Period }=A+{ }_{C}^{B}
$$

Where:
$\mathrm{A}$ : is the last period with a negative cumulative cash flow;
$\mathbf{B}$ : is the absolute value of cumulative cash flow at the end
of the period $A$;

$\mathrm{C}$ : is the total cash flow during the period after $\mathrm{A}$ 
Appendices

\section{B. Calculations for Project Wolf}

\section{PROJECT WOLF}

\begin{tabular}{|c|c|c|c|c|c|c|c|}
\hline & Year 0 & Year 1 & Year 2 & Year 3 & Year 4 & Year 5 & Year 6 \\
\hline Capital Spending & $(\$ 2,250,000)$ & & & & & & \\
\hline Salvage Value & & & & & & 0 & \\
\hline Cash Inflows & & $\$ 955,000$ & $\$ 955,000$ & $\$ 955,000$ & $\$ 955,000$ & $\$ 955,000$ & \\
\hline Material Costs & & $(\$ 14,400)$ & $(\$ 15,480)$ & $(\$ 16,641)$ & $(\$ 17,889)$ & $(\$ 19,231)$ & \\
\hline Other Expenses & & $(\$ 18,000)$ & $(\$ 16,650)$ & $(\$ 15,401)$ & $(\$ 14,246)$ & $(\$ 13,178)$ & \\
\hline Foregone Rental Income & & $(\$ 75,000)$ & $(\$ 75,000)$ & $(\$ 75,000)$ & $(\$ 75,000)$ & $(\$ 75,000)$ & \\
\hline EBIT & & $\$ 847,600$ & $\$ 847,870$ & $\$ 847,958$ & $\$ 847,865$ & $\$ 847,591$ & \\
\hline Taxes $(20 \%)$ & & 0 & $\$ 169,520$ & $\$ 169,574$ & $\$ 169,592$ & $\$ 169,573$ & 169518.2 \\
\hline Net Cash flows & $(\$ 2,250,000)$ & $\$ 847,600$ & $\$ 678,350$ & $\$ 678,384$ & $\$ 678,273$ & $\$ 678,018$ & $(\$ 169,518)$ \\
\hline Cumulative Cash Flows & $(\$ 2,250,000)$ & $(\$ 1,402,400)$ & $(\$ 724,050)$ & $(\$ 45,666)$ & $\$ 632,607$ & $\$ 1,310,625$ & $\$ 1,141,107$ \\
\hline Discount Factor & 1 & 0.91 & 0.83 & 0.75 & 0.68 & 0.62 & 0.56 \\
\hline Present Values & $-2,250,000$ & 771316 & 563030.5 & 508788 & 461225.912 & 420371.16 & -94930.19 \\
\hline Net Present Value (NPV) & & & & & & & $\$ 379,801$ \\
\hline $\begin{array}{l}\text { Internal Rate of Return } \\
\text { (IRR) }\end{array}$ & & & & & & & $17 \%$ \\
\hline
\end{tabular}

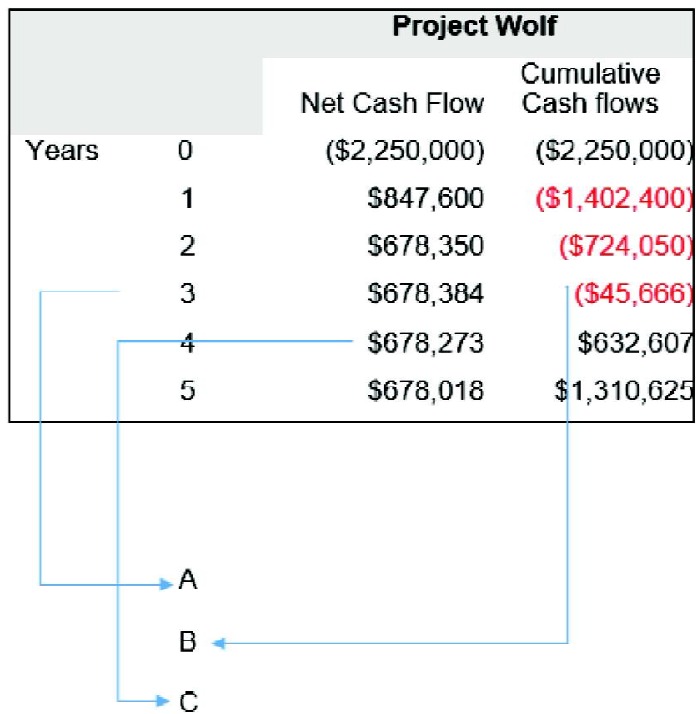

To calculate the payback period, we have used the formula given by IIfanullah (2018) which is used for uneven cash flows:

$$
\text { Payback Period }=\mathrm{A}+\frac{\mathrm{B}}{\mathrm{C}}
$$

Where:

A: is the last period with a negative cumulative cash flow:

B: is the absolute value of cumulative cash flow at the end

of the period $A$;

$\mathrm{C}$ : is the total cash flow during the period after $\mathrm{A}$

Cite this article as: Sixbert Sangwa (2021). Capital Investment A pprai sal Report for A YR Co.: Comparative A nalysis of Project Aspirevs Wolf. International J ournal of M anagement Research and Economics. 1(4), 15-23. doi: 10.51483/ IJMRE.1.4.2021.15-23. 